\title{
PERAN TRAVEL BLOGGER DALAM MEMPROMOSIKAN PARIWISATA DI INDONESIA
}

\author{
Dini Salmiyah Fithrah Ali ${ }^{1}$ \\ Fakultas Komunikasi dan Bisnis \\ Telkom University \\ dinidjohan@gmail.com \\ Itca Istia Wahyuni ${ }^{2}$ \\ Fakultas Komunikasi dan Bisnis \\ Telkom University \\ cha.istia@gmail.com
}

\begin{abstract}
ABSTRAK
Perkembangan teknologi memberikan banyak perubahan dalam pola komunikasi. Salah satu komunikasi massa yang banyak terpengaruh oleh teknologi adalah media massa dengan munculnya new media. Keberadaan new media mencakup teknologi informasi dan teknologi komunikasi yang saling melengkapi melalui media internet, salah satu caranya adalah dengan menggunakan media sosial. Media sosial yang banyak digunakan adalah blog. Berbagai jenis blog muncul, salahsatunya adalah travel blog. Travel blog berisikan informasi mengenai tempat pariwisata. Banyak blog berisikan rekomendasi tempat pariwisata serta foto lokasi pariwisata tertentu ditambahkan dengan kisah personal yang mampu memberikan nilai tambah dalam menceritakan keindahan alam Indonesia. Tujuan penelitian ini adalah untuk mengetahui bagaimana peran travel blogger dalam mempromosikan pariwisata di Indonesia. Metode penelitian yang digunakan adalah metode penelitian kualitatif. Peneliti melakukan wawancara dengan narasumber utama dan pendukung untuk mendapatkan data valid yang kemudian dianalisa oleh peneliti agar dapat dideskripsikan menjadi sebuah hasil penelitian yang menarik dan temuan yang akan berguna untuk kementrian pariwisata Indonesia dan industri pariwisata secara umumnya.
\end{abstract}

Kata Kunci: Blog, Blogger, Travel, Pariwisata, Media Sosial, Kementrian Pariwisata 


\title{
THE ROLE OF TRAVEL BLOGGER IN PROMOTING INDONESIA TOURISM
}

\begin{abstract}
Technology provides changes in communication patterns. One of mass communication tools that affected by technology is the emergence of new media. The existence of new media includes information technology and communication technology that complement each other through the internet using social media especially blog with various types including travel blog. Travel blog contains information about the place of tourism. Many blogs contain recommendations the places of tourism as well as photos of certain tourism locations with personal stories that can provide added value in telling the natural beauty of Indonesia. The purpose of this study is to elaborate the role of travel bloggers in promoting tourism in Indonesia.The methods, which are used to answer the research question, have been collected through qualitative research, which include personal interview with main and supporting informan to obtain valid data then analyzed it to be described into results and findings that will be useful for the Indonesian Tourism Ministry and Tourism Industry generally.
\end{abstract}

Keywords: Blog, Blogger, Travel, Tourism, Social Media, Tourism Ministry

\section{PENDAHULUAN}

Perkembangan teknologi memberikan banyak perubahan dalam polakomunikasi.Salah satu komunikasi massa yang banyak terpengaruh oleh teknologi adalah media massa dengan munculnya new media. Keberadaan new media mencakup teknologi informasi dan teknologi komunikasi yang saling melengkapi melalui media internet. Aktivitas melalui new media banyak dilakukan menggunakan media sosial dimana melalui akun yang dimiliki pengguna dapat saling berkomunikasi dan berbagi informasi baik melalui tulisan, gambar, grafik, suara, video dan media lainnya. Jumlah pengguna media sosial aktif di tahun 201679.0 milyar pengguna sosial media yang aktif di Indonesia. Berikut adalah data pengguna media sosial di Indonesia pada tahun 2016:

Gambar 1.1: Diakses pada tanggal 29 Maret 2017, pukul 12.30 wib

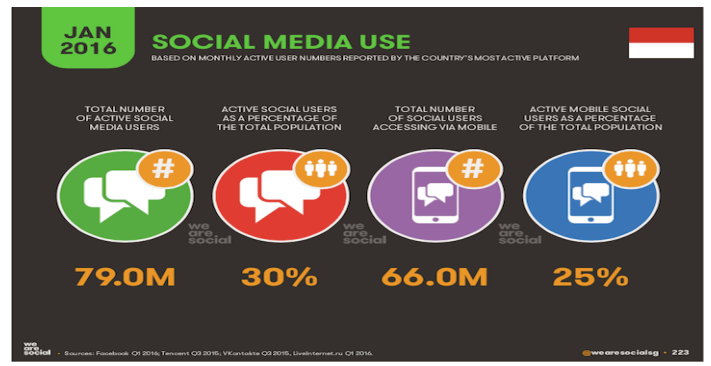

Sumber: wearesocial.net 
Salah satu media sosial yang banyak digunakan adalah blog. Jumlah blogger di Indonesia meningkat pesat dalam beberapa tahun terakhir. Hal ini terjadi karena aplikasi blog yang semakin mudah digunakan dan terdapat pilihan bahasa Indonesia. Faktor pendorong lainnya adalah biaya mengakses internet yang lebih murah dan akses Internet lebih cepat (tekno.tempo.com, 11 Jan 2016). Blog menjadi sarana bagi seseorang untuk menuangkan buah pemikirannya secara pribadi sehingga blog sejatinya menjadi alat untuk menggambarkan opini, sifat dan label diri sendiri. Jumlah pengguna blog yang semakin meningkat menjadikan blog sebagai media marketing yang sangat efektif dan memberikan banyak peluang bisnis bagi penggunanya. Secara bersamaan, seorang penulis blog sedang melakukan proses-branding kepada pembacanya sehingga muncul sebuah gambaran dan value dari pembaca.

Berbagai jenis blog muncul, salahsatunya berisikan informasi mengenai tempat pariwisata.Banyak blog berisikan rekomendasi tempat pariwisata serta foto lokasi tertentu ditambahkan dengan kisah personal dari penulisnya yang menambah keindahan alam Indonesia. Beberapa blog memberikan informasi tambahan mengenai cara menuju lokasi, infrastruktur, transportasi, biaya serta berbagai topik yang terkait dengan destinasi pariwisata tersebut.Penelitian difokuskan pada blogger NilaTanzil sebagai salah seorang travel blogger Indonesia yang merupakan Founder\&CEO TravelParks and Rainbow-Reading Garden. Informan juga merupakan kontributor resmi blog Kementrian Pariwisata Republik Indonesia sehingga mendapat kesempatan untuk melakukan perjalanan wisata yang digagas oleh kementrian dan menuliskan pengalaman hasil wisata didalam website resmi Kementrian Pariwisata.

\section{KAJIAN PUSTAKA}

\section{Teori Komunikasi Dunia Maya}

Perubahan terbesar dibidang komunikasi 40 tahun terakhir (sejak munculnya TV) adalah penemuan dan pertumbuhan Internet. Internet adalah jaringan komputer dunia yang mengembangkan ARPANET, suatu sistem komunikasi yang terkait dengan pertahanan-keamanan yang dikembangkan pada tahun1960-an. Manfaat sistem komunikasi yang berjaringan ini dengan cepat ditangkap oleh peneliti dan pendidik secara umum. Akhir-akhir ini, melalui komputer dirumah,modem, dan warnet serta melalui layanan seperti web -TV, internet hadir untuk publik. Pada keadaan seperti inipun masih ada beberapa orang yang tak setuju bahwa internet merupakan sebuah media massa baru. Internet memungkinkan hampir semua orang di belahan dunia manapun untuk saling berkomunikasi dengan cepat dan mudah.(SeverinTankard,2001).

\section{Jejaring Sosial untuk Brand}

Dalam buku Branding Promotion with Social Network, (Juju\&Sulianta,2009) dideskripsikan tentang : Apa kekuatan dari Internet Social media atau dalam ruang lingkup yang lebih sempit berupa "jejaring sosial"? Social media mengusung kombinasi antara ruang lingkup elemen dunia maya, 
dalam produk-produk layanan online seperti blog, forum diskusi, chat room, email, website dan juga kekuatan komunitas yang dibangun jejaring sosial.

Apa yang dikombinasikan didalamnya memberikan efek "power" tersendiri karena basis pembangunannya berupa teknologi dan juga "berbagai media interaksi" yang dikomunikasikan dengan teks, gambar, foto, audio juga video. Ditambah lagi dengan elemen jejaring sosial yang memang ditujukan untuk terkoneksi, berkomunikasi bahkan saling berbagi /sharing. Di dalamnya terjalin denyut aktivitas yang kaya yang dimotori oleh kepentingan komunikasi , orangorang yang tergabung saling berbagi pendapat, sudut pandang, juga berbagi alat komunikasi digunakan untuk mempertegas penyampaian.

Setiap media sosial era internet memang memiliki porsi yang luar biasa besar untuk dijadikan media informasi, tetapi porsinya terus mengalami degradasi dan penyusutan dengan diambil alihnya sebagai peran-peran dengan teknologi yang lebih kaya. Meskipun tampaknya televisi tidak tergantikan, tetap saja proporsi media televisi terus mengalami penyusutan dan teknologi berbasis internetlah yang menjadi alat yang mulai digunakan dan akan terus digunakan untuk masa-masa mendatang.

\section{Gambar 2: Social Media dari masa ke masa}

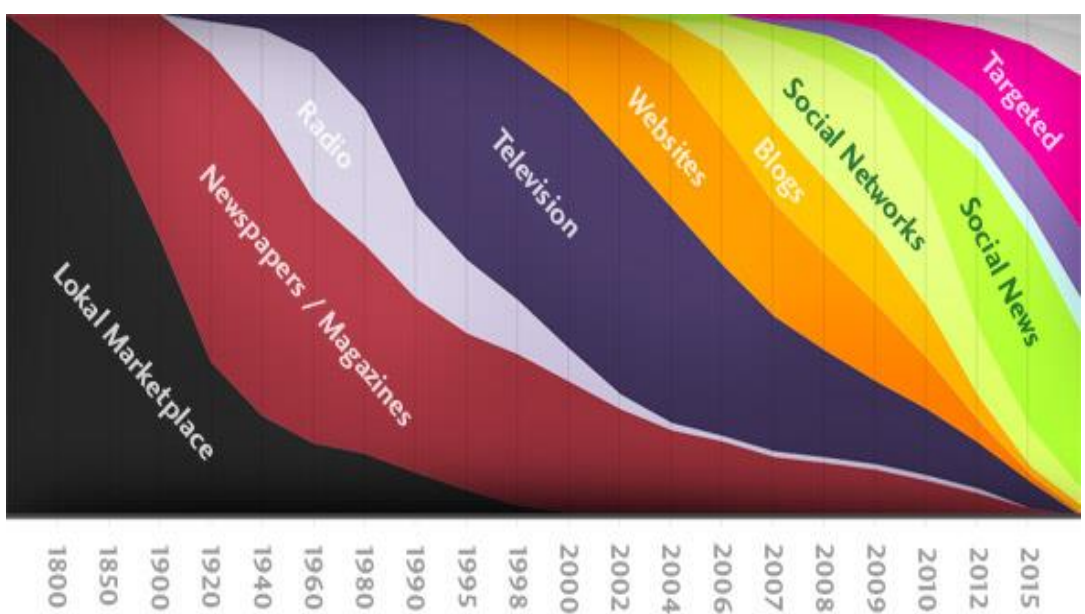

Sumber: Juju\&Sulianta, 2009:2

Dimulai tahun 2009, jejaring sosial berkiprah dengan bendera "everything is Social", berbeda dengan media -media lainnya, aksi jejaring sosial tidak terbendung, bahkan website yang ada saat ini pun secara tidak langsung didorong untuk ikiut mengibarkan bendera jejaring sosial. Faktanya setiap website memiliki account jejaring sosial, entah itu Facebook, atau twitter atau lainnya.

Jejaring sosial secara umum dalam wujud bisnis, konteksnya meluas dan melibatkan juga berbagai social media serta elemen yang tidak terpisahkan dari jejaring sosial.Aksi bolak balik yang terjalin diantara keduanya, antara jejaring sosial dan social media semakin kuat terasa, ada kebutuhan timbal balik diantara keduanya. Dan memang pada dasarnya jejaring sosialpun merupakan produk 
sosial media, tetapi seraya orang-orang menggunakan dan beraktivitas dengan keduanya, pembedanya dalam hal" kepentingan "semakin bias".

Anda pasti menemukan berbagai account jejaring sosial seperti Facebook atau twitter yang juga dijadikan sebagai "image terpampang" dari suatu website untuk membangunjejaringnya lebih luas lagi. Demikian pula, dalam jejaring sosial, anda dapat melekatkan berbagai konten yang juga menjadi bagian sosial media dalam situs jejaring sosial anda. Inilah mengapa saya katakan efek bolak balik karena keduanya saling mendukung dan pada praktek keduanya saling diletakkan karena fondasi sama-yaitu Internet. Social media ini suatu objek, suatu produk yang dibentuk dan bertujuan, pastinya memiliki karakteristik tersendiri yang membedakan dengan media sosial tradisional lain meskipun semuanya tetap saja menyerukan pemikiran dan gagasan. Berikut karakteristik pada social media modern:

1) Transparansi: segalanya tampak keterbukaan karena elemen dan materi memang ditujukan untuk konsumsi publik atau sekelompok orang.

2) Dialog dan Komunikasi: didalamnya akan terjalin suatu hubungan yang sepenuhnya berupa komunikasi, misalnya antara brand dengan para "fans" nya.

3) Jejaring Relasi: hubungan antara elemen-elemen penyusunan akan terjalin dan juga relasi ini akan terbentuk pula antara individu atau kumpulan individu atau suatu perwakilan yang dimotori oleh individu.

4) Multi Opini: setiap orang akan berargumen dan setiap orang memiliki pandangan yang relatif, entah itu benar, salah atau berada dalam grey area, ini tertuang dalam wujud komunikasi sebagai medianya.

5) Multi Form : Wujudnya dapat berupa: social media press release, video news release, internet dan elemen penyusun lainnya, komunitas jejaring sosial sebagai infuencer atau kombinasi diantaranya.

Sosial media dapat dipandang sebagai tool saat anda ingin mendapatkan keuntungan darinya. Dengan memandangnya sebagai tools, secara praktis anda akan lebih fleksibel dengan cara anda sendiri, menggunakan untuk tujuan-tujuan tertentu. Tool jika dilihat dari karakteristik dan hasil nyata, justru memunculkan peluang-peluang yang tidak sendirinya terbentuk begitu saja, peluang-peluang ini harus dimanfaatkan agar berhasil guna. Peluang-peluang yang diharapkan antara lain:

1) Life Sharing. Berbagi aktivitas hidup ini seperti berbagi foto, video, dan tool yang digunakan seperti, youtobe atau Flickr.

2) Knowledge Sharing atau berbagai pengetahuan, umumnya menggunakan tool: Blogs dan Microblog seperti misalnya Twitter, Wordpress, Blogger, dan blogspot.

3) Network dan Komunitas. Social Networking: dengan membangun jejaring sosial otomatis anda dapat terhubung dan saling berinteraksi dengan jejaring yang terbentuk. Business Network. Membentuk jejaring sosial keperluan bisnis, sebenarnya tidak berbeda dengan jejaring lain, interaksi yang terjadipun reatif sama, hanya saja tool untuk jejaring bisnis dapat anda gunakan terspesifik, misalnya: linkedin. 
4) Community Building: membangun komunitas ini bukan hal yang mudah juga, tetapi jika komunitas sudah terbangun. Komunitas dapat mengumpulkan informasi dan mempelajari komunitas tanpa harus menggunakan data-data sample, karena data-datanya sudah terbentang sempurna dalam komunitas.

5) Information Spreading: Jejaring sosial dan berbagai social media mampu menyebarkan informasi dengan cepat dengan menjangkau sebar yang luar biasa dibandingkan dengan media lain manapun. Keunggulannya seperti efisiensi biaya dan efektivitas informasi yang disampaikan alasan mengapa metode ini sangat diminati. (sumber: Juju \& Sulianta,2009).

\section{Pariwisata dan Brand Destinasi}

Pariwisata modern mau tidak mau harus merencanakan dan membangun brand- nya untuk tiga hal, yaitu media publikasi dan pemasaran, sebagai identitas destinasi dan sebagai ketahanan nasional. Sebagai media komunikasi dan pemasaran brand telah diperbincangkan di bagian lain sebelumnya, khususnya komunikasi pemasaran. Jadi dibagian ini dijelaskan tentang hubunganpariwisata dan brand sebagai identitas destinasi serta pariwisata dan brand destinasi sebagai ketahanan nasional.Penjelasan mengenai hal ini, khususnya pencapaian brand dan identitas destinasi merupakan masalah penting., sekaligus masalah yang sulit bagi destinasi-destinasi khususnya di Indonesia. Hal ini disebabkan karena Pemahaman masyarakat terhadap pariwisata, Regulasi, Kelembagaan masyarakat adat, Koordinasi, Industri dan profesional (Bungin, 2015).

\section{Blog}

Blog adalah platform paling konvensional di ranah media sosial karena menyuguhkan informasi dengan pola yang biasa dilakukan oleh mediamassa. Namun di sisi lain, blog juga merupakan media sosial paling penting karena disinilah para pengguna internet memuat konten secara utuh dan lengkap, baik berupa artikel, rangkaian foto maupun video. Platform diluar blog fokus pada percakapan, ekspresi dan interaksi. Fitur-fitur yang memungkinkan sebuah konten ditayangkan secara lebih canggih biasanya dikembangkan di blog, termasuk fitur yang membuat tampilannya jadi lebih menarik saat muncul dijejaring media sosial lainnya.Setiap lembaga perlu memiliki blog, karena lewat media seperti inilah konten-konten ringan dan dekat dengan karakter pengguna media sosial dapat leluasa dibuat untuk disebarkan. Pikirkanlah seberapa jauh sebuah website resmi lembaga dapat mengkreasikan konten-konten yang ringan,menarik dan keluar-dari-kotak (out ofthe box). Ketika hendak membuat konten kreatif, tim media sosial mungkin akan terbentur pada aturan baku atau pakem yang berlaku di Kementerian Perdagangan, bisa jadi bertentangan dengan citra dan ekspektasi masyarakat terhadap lembaga tersebut. Maka tidak mengherankan jika informasi di situs web pemerintah selalu tampil dalam bahasa formil yang kurang menarik perhatian banyak orang. Tidak mengejutkan pula jika pengakses situs web instansi pemerintah hanya berasal dari kalangan tertentu, termasuk wartawan, yang berkepentingan mendapatkan bahan berita untuk dimuat di medianya masing-masing. 
Di era digital seperti sekarang ini, eksistensi blog sangatlah penting, karena ini terkait erat dengan apa yang ingin disampaikan oleh lembaga tersebut(what to say). Biasanya, ada saja keluhan yang muncul saat sebuah media massamerilisi nformasi yang bersumber dari artikel yang dibuat oleh tim humas kementerian. Latarbelakang informasinya tidak lengkap.Datanya salah kutip. Seringkali judul dan isi beritanya salah-arah sama sekali (miss-leading). Untuk mengatasi atau setidaknya menetralisir risiko tersebut, opsi menyampaikan sendiri sebuah informasi ke pengguna-akhir layak dipertimbangkan.Selanjutnya, blog juga terkait dengan carapenyampaian informasi (how to say). Kalau masyarakat hanya akan membaca artikel yang isinya ringan atau artikelyang dikemas dengan gaya bahasa populer,mengapatidak mencoba memenuhi kebutuhan tersebut. Semua ini hanya bisa diakomodir lewat sebuah blog yang genetik dibuat untuk menampungcatatan-catatanringan. Dalam hal ini, sebuah instansi secara parallel dapat mengelola konten kedalam blogresminya dan mengajak para blogger untuk menulis seputar tema atau isu yang sedang diangkat (Kementrian Perdagangan, 2014).

\section{Blogger}

Pada tahun 1998 Google muncul sebagai mesin pencari utama di internet dan memunculkan tampilan indeks.Laju perkembangan jejaring sosial begitu evolutif. Tahun 1999 muncul situs yang dapat digunakan untuk membuat blog pribadi, yaitu Blogger. Situs ini memberi peluang kepada penggunanya untuk dapat membuat halaman situs sendiri. Dengan demikian pengguna Blogger bisa memuat halaman blognya dengan berbagai informasi, seperti hal atau pengalaman bersifat pribadi dan ide, kritik serta pendapatnya mengenai suatu topic persoalan yang sedang hangat. Blogger inilah-karenakonten- kontennya-yang dikemudian hari disebut-sebut sebagai tonggak penting perkembangan media sosial. Pada tahun 2000 tercatat lahir sejumlah situs sosial dengan corak tersendiri seperti Lunarstorm, Live Journal, Cyword yang fungsinya sekadar memperluas informasi secara searah. Domain dot com menjadi populer, dimana saat itu 70 juta computer terhubung ke internet. Kepentingan para pebisnis pun muncul di situs jejaring dengan munculnya Ryze.com pada tahun 2001. Situs ini bertujuan untuk memperluas dan memperbesar jejaring bisnis. Beragam kepentingan yang lebih spesifik makin bermunculan dalam situs.Kemudian pada tahun 2001, Wikipedia, sebuah ensiklopedia online dan wiki terbesar di dunia muncul.

Berikutnya pada 2002, muncul Friendster sebagai situs anak muda pertama yang semula disediakan untuk tempat pencarian jodoh. Konektivitas dalam jaringan maya menjadi awal untuk kemudian dapat disusul dengan temu darat. Oleh karena itu, situs ini lebih diminati anak muda untuk saling berkenalan. Friendster mengalami booming dan kehadirannya begitu fenomenal. Bak jamur yang tumbuh di musim hujan, dalam waktu singkat bermunculan situs sosial interaktif lain menyusul Friendster. Seakan Friendster tidak dibiarkan eksis sendirian dalam jangka waktu lama, karenasejak 2003 terus bermunculan berbagai medsos dengan seabrek keunggulan, keunikan, karakteristik dan segmentasi yang beragam. LinkedIn yang lahir tahun 2003, muncul semata-mata tidak hanya untuk bersosialisasi saja. Situs ini juga bermanfaat untuk bertukar 
informasi mengenai pekerjaan atau mencari pekerjaan, sehingga fungsi media sosial makin berkembang.Tahun 2003 lahirpula MySpace. Kemudahan dalam penggunaan ditawarkan oleh MySpace, sehingga situs jejaring sosial ini bisa dikatakan begitu mudah digunakan atau user friendly. Hingga akhirtahun 2005, Friendsterdan MySpace merupakan situs jejaring sosial yang paling diminati. Kemunculan sejumlah situs jejaring sosial itu pada intinya bermula dari adanya inisiatif untuk menghubungkan orang-orang dari berbagail latar belakang yang ada di seluruh belahan bumi.Dalam perkembangan lebih lanjut, media sosial kini menjadi sarana atau aktivitas yang masuk kategori digital marketing, karena banyak dijejali kemasan dan muatan pemasaran.Salah satu unsur mendasar yang ada pada situs-situs media sosial tersebut adalah fungsi dan layanan jejaring sosial. Layanan jejaring sosial memberikan jasa konektivitas melalui situs, platform dan sarana yang berfungsi memfasilitasi pembentukan jaringan atau hubungan sosial diantara beragam orang yang mempunyai ketertarikan, minat (interest), kegiatan, latarbelakang, maksud, kepentingan, tujuan, atau korelasi dunia nyata yang sama. Sebuah layanan jejaring sosial biasanya terdiri atas representasi setiap penggunanya dalam wujud profil, aktivitas, relasi sosial dan sejumlah layanan tambahan. Layanan itu biasanya berbasis web dan penggunanya berinteraksi melalui internet, seperti pesan instan, surat elektronik dan mengunduh foto, gambar atau video. Berbagai situs jejaring sosial memudahkan pengguna untuk berbagi ide, saran, pandangan, aktivitas, informasi, acara, ajakan dan ketertarikan di dalam jaringa individu masing-masing orang. Selain layanan jejaring sosial bersifat terpusat pada individu, sosok atau tokoh,berkembang pula layanan komunitas yang sifatnya lebih terpusat pada grup atau kelompok bersama.

Pada tahun 2004 Facebook lahir.Situs jejaring sosial ini sampai kini masuk dalam jajaran lima besar yang paling dikenal karena memiliki banyak anggota. Memasuki tahun 2006, penggunaan Friendsterdan MySpace mulai tergeser dengan adanya Facebook.Situs ini dengan corak tampilan yang lebih modern memungkinkan orang untuk berkenalan dan mengakses informasi seluasluasnya.Tahun 2006 Twitterlahir.Kemunculan Twitter menambah jumlah situs sosial bagi kaum muda. Pengguna Twitter hanya bisa meng-update status yang bernama tweet atau kicauan dan dibatasi hanya 140 karakter saja. Twitter menggunakan system mengikuti- tidak mengikuti (follow-unfollow), dimana seseorang dapat melihat status terbaru dari orang yang diikuti (follow). Pada 2007 Wiser lahir.Situs jejaring sosial ini meluncur bertepatan dengan peringatan Hari Bumi (22April) 2007, dengan tujuan menjadi sebuah direktori online organisasi lingkungan seluruh dunia termasuk gerakan pro lingkungan hidup yang dilakukan individu, organisasi dan kelompok. Tidak mau ketinggalan oleh situs jejaring sosial yang lebih dulu eksis, Google pada tahun 2011 mengeluarkan Google + .Situs jejaring sosial ini diawal peluncurannya hanya terbatas pada orang yang telah di-invite oleh Google. Akan tetapi tidak lama kemudian, Google+ diluncurkan secara umum. Tahun 2012 muncul Ketiker. Situs untuk semua usia ini menambah daftar panjang situs-situs jejaring sosial. Situs web ini lebih menawarkan jejaring sosial berupa mikroblog yang memberi peluang bagi penggunanya untuk mengirim dan membaca pesan secara leluasa. Belakangan, kemunculan Line, WeChat, KakaoTalk dan lainnya terus menambah panjang 
daftar situs-situs jejaring sosial yang sudah ada. Hal itu ditopang oleh kemajuan perangkat gadget, teknologi informasi dan kecepatan jaringan internet yang makin pesat. (Kementrian Perdagangan,2014).

\section{Promosi}

Promosi menurut Tjiptono (2000:200) adalah semua kegiatan yang dimaksudkan untuk menyampaikan atau menginformasikan suatu produk kepada pasar sasaran, untuk memberi informasi tentang keistimewaan, kegunaan dan yang paling penting adalah tentang keberadaannya, untuk mendorong orang bertindak. Aktivitas promosi sebagai bentuk komunikasi yang memberikan informasi kepada masyarakat tentang produk atau jasa yang ditawarkan oleh perusahaan sebagai dasar pengembangan kegiatan promosi adalah komunikasi. Komunikasi sendiri adalah proses penyampaian suatu pesan oleh seseorang kepada orang lain untuk memberitahu atau mengubah sikap, pendapat atau perilaku, baik langsung secara lisan, maupun melalui media (Uchjana, 1993:55).

Promosi sebagai suatu kegiatan yang dilakukan oleh perusahaan untuk mengkomunikasikan manfaat dari produknya dan untuk meyakinkan konsumen agar membeli.Cummins dalam Rangkuti (2009:177) mendefinisikan promosi sebagai serangkaian teknik yang digunakan untuk mencapai sasaran penjualan atau pemasaran dengan penggunaan biaya yang efektif, dengan memberikan nilai tambah pada produk atau jasa baik kepada perantara maupun pemakai langsung, biayanya tidak dibatasi dalam jangka waktu tertentu.Dari beberapa definisi tersebut, dapat disimpulkan bahwa promosi adalah kegiatan yang bertujuan untuk mempengaruhi seseorang agar mereka tertarik akan suatu produk dan kemudian membelinya, sehingga terjadi pertukaran dalam pemasaran.

\section{Bauran Promosi}

Menurut Rangkuti (2009:23), bauran promosi (promotion mix) merupakan bagian dari bauran pemasaran (marketing mix) yang secara umum terdiri dari Product, Price, Place, Promotion memiliki fungsi yang sama, tetapi bentuk-bentuk tersebut dapat dibedakan berdasarkan tugas-tugas khususnya. Beberapa tugas khusus itu sering disebut bauran promosi (promotion mix), meliputi:1)Advertising atau periklanan adalah komunikasi non individu dengan sejumlah biaya,melalui berbagai media yang dilakukan oleh perusahaan, lembaga nirlaba serta individu; 2) Sales Promotion atau promosi penjualan adalah salah satu kegiatan promosi untuk melakukan rangsangan kepada konsumen untuk melakukan pembelian segera; 3)Personal Selling atau penjualan perseorangan adalah interaksi antar individu ,saling bertemu muka yang ditujukan untuk menciptakan, memperbaiki, menguasai atau mempertahankan hubungan pertukaran yang saling menguntungkan dengan pihak lain; 4)Direct Marketing merupakan salah satu kegiatan penjualan secara langsung kepada konsumen untuk melakukan pembelian; 5)Public Relations, yaitu usaha untuk merangsang permintaan terhadap suatu produk secara nonpersonal dengan membuat beritayang bersifat komersial tentang produk tersebut dalam media tercetak atau bukan, maupun hasil wawancara yang disiarkan dalam media tersebut. 


\section{Tujuan Promosi}

Tujuan promosi adalah untuk mempengaruhi konsumen dalam mengambil keputusan untuk membeli suatu barang atau jasa demi meningkatkan profit perusahaan. Dengan demikian kegiatan promosi haruslah dilakukan berdasarkan atas beberapa hal yang telah direncanakan dengan matang sebelumnya sehingga tujuan yang diharapkan perusahaan dapat tercapai. Menurut Tjiptono (2000:222), tujuan promosi diantaranya adalah:

a. Menumbuhkan persepsi pelanggan terhadap suatu kebutuhan (categoryneed)

b. Memperkenalkan dan memberikan pemahaman tentang suatu produk kepada konsumen(brand awareness)

c. Mendorong pemilihan terhadap suatu produk(brand attitude)

d. Membujuk pelanggan untukmembelisuatu produk (brand purchaseintention)

e. Mengimbangi kelemahanunsur bauran pemasaranlain (purchase facilitation)

f. Menanamkancitraproduk dan perusahaan(positioning)

Menurut Goh (2003:138), tujuan promosi secara sederhana bisa dipersempit menjadi tiga jenis tujuan:

a. Memberikan informasi pelanggan tentang produk atau fitur baru seperti menciptakan kebutuhan.

b. Mempengaruhi pelanggan untuk membeli merek orang lain. Mengingatkan pelanggan tentang merek,yang termasuk memperkuat penetapan ancangan merek.

Menurut Basu danIrawan (2001:353), tujuan promosi adalah:

a. Modifikasi tingkah laku: kegiatan promosi yang dilakukan sebagai usaha untuk mengubah tingkah laku yang sudah ada. Penjualakanselalu berusaha memberikan kesan baik pada produk yang dijualnya.

b. Memberitahu: kegiatan promosi ditujukan untuk memberitahukan pasar yang dituju tentang penawaran perusahaan. Promosi yang bersifat informasi umumnya lebih sesuai dilakukan pada tahap-tahap awal didalam siklus kehidupan produk. Kiranya hal ini merupakan masalah penting untuk meningkatkan permintaan. Sebagian orang tidak akan membeli barang atau jasa sebelum mereka mengetahui produk tersebut dan apa manfaatnya. Promosi yang bersifat memberitahukan penting bagi konsumen karena dapat membantu pengambilan keputusan untuk membeli.

c. Membujuk: promosi yang bersifat membujuk kurang disenangi orang namun kenyataannya sekarang ini kebanyakan yang muncul adalah promosi yang bersifat membujuk. Promosi seperti ini diarahkan untuk mendorong pembelian.Sering perusahaan tidak ingin memperoleh tanggapan secepatnya tetapi lebih mengutamakan untukmenciptakan kesan positif. Hal ini dimaksudkan agar dapat memberikan pengaruh dalam waktu yang lama terhadap perilaku pembeli.

d. Mengingatkan: Promosi yang bersifat mengingatkan, dilakukan untuk mempertahankan merek produk di hati masyarakat dan perlu dilakukan selama tahap kedewasaan didalam siklus kehidupan produk. Ini berarti hak perusahaan berusaha untuk paling tidak mempertahankan pembeli yang ada.Jadi secara singkat promosi berkaitan dengan upaya bagaimana orang dapat mengenal 
produk perusahaan, lalu memahaminya dan berubah sikap, menyukai, dan yakin untuk membeli.

\section{Promosi Online}

Menurut Rangkuti (2009:228), Internet dapat dipakai sebagai alat komunikasi pemasaran secara online. Unsur-unsur komunikasi pemasaran dalam internet meliputi: iklan, salespromotion, public relations, direct marketing dan personal selling. Model komunikasi secara online sering disebut juga dengan online marketing communication mix. Indikator- indikator yang digunakan, sama seperti dalam membuat program promosi bisnis yang sudah ada. Perbedaan hanya pada indikator yang digunakan seperti iklan yang dicerminkan oleh banyaknya link ke situs lainnya. Public Relations dicerminkan oleh FAQ section, presscenter, press release, photogallery, registration untuk menerima $e$ newsletter, testimonial atau online guessbook, rekomendasi untuk dikirim ke relasi, serta send e-postcards. Sedangkan online selling meliputi online booking facility atau fasilitas pemesanan lewat email.

Promosi online adalah strategi yang disusun untuk melakukan promosi secara online salah satunya dengan menggunakan media internet.Online disini artinya terhubung, terkoneksi aktif dan siap untuk berkomunikasi dengan atau dikontrol oleh komputer. Promosi merupakan koordinasi dari seluruh upaya yang dimulai pihak penjual untuk membangun berbagai saluran informasi persuasi untuk menjual barang dan jasa atau untuk memperkenalkan suatu gagasan (Morissan, 2010).

\section{Pariwisata dan Destinasi Pariwisata}

Menurut Salah Wahab dalam Yoeti (1983:106), pariswisata ialah suatu aktivitas manusia yang dilakukan secara bergantian diantara orang-orang dalam suatu negara itu sendiri di luar negeri untuk sementara waktu dalam mencari kepuasan yang beranekaragam dan berbeda-beda dengan apa yang dialaminya dimana ia memperoleh pekerjaan tetap. Menurut Dr. Hubert Gulden dalam Yoeti (1983:108), kepariwisataan adalah suatu seni dari lalulintas orang, dimana manusia-manusia berdiam di suatu tempat asing untuk maksud tertentu, tetapi dengan kediamannya tersebut tidak boleh dimaksudkan akan tinggal menetap untukmelakukan pekerjaan selama-lamanya atau meskipun sementara waktu, sifatnya masih berhubungan dengan pekerjaan.

Sedangkan pariwisata menurut ismayanti (2010:1) adalah kegiatan dinamis yang melibatkan banyak manusia serta menghidupkan berbagai bidang usaha. Berdasarkan pendapat tersebut dapat diketahui bahwa sektor pariwisata merupakan salah satu sektor yang menguntungkan. Pariwisata berkembang karena adanya getaran manusia dalam mencari sesuatu yang belum diketahui, menjelajahi wilayah baru, mencari perubahan suasana atau untuk mendapatkan perjalanan baru.

Ketika melakukan perjalanan, pasti terdapat daerah yang dituju. Daerah inilah yang disebut daerah tujuan wisata.Sesuai Undang-Undang Republik Indonesia Nomor 10 Tahun 2009 tentang Kepariwisataan, Daerah Tujuan Wisata yang selanjutnya disebut Destinasi Pariwisata adalah kawasan geografis yang 
berada dalam satuatau lebih wilayah administrasi yang didalamnya terdapat daya tarik wisata, fasilitas umum, fasilitas pariwisata, aksesibilitas serta masyarakat yang saling terkait dan melengkapi terwujudnya kepariwisataan. Menurut Mariotti dalam Jafar Hafzah(1999:43), daerah tujuan wisata harus memiliki hal menarik yang dapat ditawarkan kepada para wisatawan. Destinasi pariwisata harus memenuhi tiga syarat yaitu:

1. Harus memiliki something to see, yaitu tempat tersebut harus ada objek dana traksiwisata khusus yang berbeda dengan apa yang dimiliki daerah lain untuk dilihat.

2. Harus menyediakan something to do, yaitu di tempat tersebut harus disediakan fasilitas untuk melakukan kegiatan rekreasi yang dapat membuat betah wisatawan.

3. Harus menyediakan something to buy, yaitu ditempat tersebut harus tersedia fasilitas untuk berbelanja,terutama oleh-oleh dan barang kerajinan khas yang dapat dibawa pulang ke tempat asal wisatawan.

Mariotti juga berpendapat bahwa ada tiga hal yang dapat menarik wisatawan untuk berkunjung ke suatu daerah. Ketiga hal tersebut adalah bendabenda yang tersedia dan terdapat di alam semesta (contoh:pemandangan, Iklim,floradanfauna); benda-benda hasil ciptaan manusia (contoh:monument dan museum); dan tatacarahidup masyarakat setempat.

\section{Promosi Pariwisata}

Menurut Liga Suryadana danVanny (2015:157), promosi dalam pariwisata adalah arus informasi satu arah yang dibuat untuk mengarahkan calon wisatawan atau lembaga usaha pariwisata kepada tindakan yang mampu menciptakan pertukaran (jualbeli) dalam pemasaran produk pariwisata. Promosi dalam pemasaran produk pariwisata berperan sebagai pendukung transaksi dengan menginformasikan, membujuk, mengingatkan dan membedakan produk pariwisata yang dipromosikan dengan pariwisata perusahaan lain.

\section{Strategi Pemasaran Pariwisata}

Perencanaan strategi tentu dilakukan oleh Kementrian Pariwisata Indonesia dimana Kementrian tersebut dapat merencanakan objek-objek nasional, ragional, ataupun lokal.Strategi tersebut tidak mungkin dilaksanakan sekaligus,tapi harus dibuat tahapannya. Langkah-langkah yang diperlukan antara lain(Alma, 2014:345):

1. Tentukan segmen pasar dimana strategi akan diarahkan,yaitu:

a. Negara atau daerah yang merupakan pasarpotensial dan cara hidup masyarakat tertentu diharapkan menjadi konsumen

b. Kelas sosial, tingkat pendidikan, dan cara hidupmasyarakat tertentu,

c. Tingkat penghasilan yang dimiliki masyarakat,

d. Anggota masyarakatyangmempunyai waktu luang

e. Keluarga-keluarga yang tidak banyak mempunyai anak, ataupun khusus ditujukan kepada kelompok anak-anak.

2. Harus diketahui apayang menjadi perhatian atau selera dari masyarakat konsumen 
3. Perhatikan faktor-faktor yang dapat mendorong permintaan konsumen seperti fasilitas, kemudahan, faktorharga, faktor produk itu sendiri, pelayanan, waktuyang tepat dan sebagainya

4. Perhatikan pula bahwa ada dua lembaga penting dalam pemasaran industry pariwisata yang perlu diperhatikan yaitu:

a. Perantara, seperti agen perjalanan

b. Konsumen akhir, wisatawan, kaum pedagang yang senang bepergian, orang yang akan mengadakan konferensi, rapat kerja dan sebagainya.

Pada tahun 2009, Direktorat Jenderal Pemasaran Kementrian Kebudayaan dan Pariwisata Republik Indonesia menerbitkan buku strategi komunikasi pemasaran pariwisata internasional (Bungin,205:2015-221). Dalam buku tersebut dijelaskan bahwa Kementrian Kebudayaan dan Pariwisata Republik Indonesia menerapkan beberapa strategi untuk merebut keberhasilan pariwisata 2009 sebagai berikut:

1. Grand Strategy

Grand Strategy yaitu struktur atau kerangka utama pengembangan pemasaran yang ditulis dalam Rencana Pembangunan Jangka Menengah danRencana Pembangunan Jangka Panjang.

2. Pull and Push Strategy

\section{a. Pull Strategy}

Strategi komunikasi pemasaran yang mempunyai tujuan menarik wisatawan secara langsung dari pemasaran dengan meningkatkan kesadaran dan kehendak untuk berkunjung ke Indonesia.

b. Push Strategy

Strategi ini bertujuan mendorong industry pariwisata dalam dan luar negeri untuk mengadakan pengenalan dan penjualan produk pariwisata Indonesia.Pemerintah Indonesia memudahkan industry dalam dan luarnegeri untuk mengadakan pertemuan, perdagangan, pengadaanbahanpromosi, kerja sama promosi dan kemudahan lain untuk mendatangkan wisatawan.

3. Strategi Penetrasi

Tujuan strategi ini adalah untuk memanfaatkan kemampuan pariwisata saat ini, bersifat tradisional, agar lebih bermanfaat bagi pemasaran pariwisata.Strategi ini dilaksanakan dengan beberapa tujuan:a. Produk lama, segmen baru Strategi ini digunakan apabila produk pariwisata belum dikenal atau masih baru, stakeholder dapat menggunakan strategi penetrasi pasar seperti penawaran produk yang semula hanya untuk perempuan dipromosikan untuk wisatawan lelaki.Misalnya paket wisatabelanja, kulinari dan spa.

a. Produk lama, kegunaan,dan kemasan baru. Strategi ini digunakan pada produk yang cukup dikenal dengan demikian pemerintah dan pihak swasta dapat memilih pertama membuat kemasan dengan cerita, kedua mengemas, menyebarkan cerita-cerita legenda yang ada di Indonesia.

b. Membentuk dan mendukung komunitas. Strategi ini ditujukan untuk memperkuat citra sosial dengan testimoni di antara komunitas tertentu. Strategi ini dapat dilakukan dengan cara; Pertama, mendukung komunitas kekerabatan atau keluarga dengan mengkomunikasikan testimony kunjungan ke Indonesia. Kedua mendukung atau membentuk komunitas 
blog di internet dengan testimony tentang destinasi Indonesia.Ketiga mendukung atau kerjasama dengan NGO maupun kelompok organisasi NGO lain terkait berbagai bidang seperti ahli arkeologi, ahli biologi, ahli lingkungan, dan ahli kesehatan.

4. Strategi Penyerangan Tidak Langsung

Ada tiga jenis pendekatan strategi menyerang tidak langsung;Pertama, keanekaragaman produk-produk yang tidak berkaitan dengan produk pesaing.Kedua, keanekaragaman pemasaran geografi baru. Ketiga, atraksi masa lalu, seperti binatang purba Dragon Komodo, Orang Utan, Badak Bercula Satu, produk pusaka seperti Borobudur, Prambanan, Kesodo Tengger, dan lainlain.

5. Strategi Pemasaran Gerilya

Strategi gerilya meliputi pemotongan harga paket wisata terpilih,mengganggu keanekaragaman produk pesaing, kejutan promosi intensif, misalnya; pertama, gerilya berkelanjutan dengan promosi yang pendek dan harga diskon untuk paket pariwisata, undian tiket penerbangan gratis, hotel gratis, pada acara penjualan langsung di beberapa lokasi pasar pesaing. Kedua, penyerangan pada pasar kecil tetapi berpotensi besar menjadi pasar pesaing. Ketiga, mendukung agen perjalanan, penerbangan lokal di pasar lokal untuk menjual produk pariwisata Indonesia.

6. Strategi Pemasaran Nicher

Ide utama strategi celah pasar adalah Indonesia mempunyai kekhususan, perbedaan dan keunikan dibanding pesaing. Celah pemasaran yang ideal adalah; Pertama, memiliki daerah cukup besar dan daya beli cukup besar agar dapat menguntungkan; Kedua, memiliki potensi untuk berkembang seperti pasar China dan Malaysia; Ketiga, diabaikan oleh para pesaing atau negara lain; Keempat, Indonesia (stakeholder pariwisata) mempunyai kemampuan dan sumber daya untuk memenuhi keperluan celah pemasaran tersebut secara efektif seperti ecotourism, diving, surfing, petualang; Kelima, Indonesia mampu membela diri dari serangan pesaing besar dengan mengkonstruksi goodwill atas produk agar janji promosi dapat terpenuhi.

7. Competitive Strategy

Strategi ini terdiri dari tiga strategi utama,yaitu differentiation strategy, focus strategy dan horizontal strategy.

a. Differentiation Strategy, Indonesia kaya akan keanekaragaman produk dan perbedaan keunikan produk. Keunikan dapat diterapkan selain pada produk juga pada pelayanan. Kunci pembedaan produk adalah karya seni sedangkan pembedaan dalam pelayanan yaitu diwarnai budaya masyarakat local yang beranekaragam.

b. Focus Strategy, Strategi ini berkait dengan geografi pasar Indonesia. Focus pada potensi pasar merupakan strategi pemasaran pariwisata Indonesia yang diterapkandengan mempertimbangkan portofolio perencanaan pemasaran pada unit pemasaran strategik.

c. Horizontal Strategy, Merupakan pendekatan pemasaran baru. KEMENBUDPAR menggunakan pendekatan ini melalui pendekatan vertical above the line dan below the line menuju pendekatan horizontal 
offline dan online. Offline melalui intimacy, mendekati komunitas pariwisata Indonesia untuk membuat kesaksian tentang destinasi dan produk pariwisata Indonesia. Dalam online melalui kegembiraan,menggunakan teknologi informasi, komunitas internet seperti blog, facebook, mailist, email, memberikan cerita atau kesaksian tentang pariwisata Indonesia.

8. Bauran dan Taktik Pemasaran

Taktik pemasaran yang digunakan mencakup keanekaragaman produk, harga paket, harga tiket kapal terbang, program weekend, program jualan mega, dan program pemasaran lainnya yang lebih khusus dan mengarah pada penjualan langsung. Disamping taktik harga, dilakukan pula taktik pengemasan dengan cerita dan citra sosial produk, secarakhusus, unik, membuat sensasi dan nilai tambah bagi wisatawan.

9. Koordinasi Pemasaran di Peringkat Negara dan Wilayah

Dalam upaya melaksanakan pembangunan pariwisata Presiden RI telah membuat instruksi Presiden RI Nomor 16 Tahun 2005 tentang Kebijakan Pembangunan Kebudayaan dan Pariwisata. Presiden Indonesia mengarahkan para Menteri Kabinet Indonesia Bersatu, para Kepala Lembaga Pemerintah Non-Departemen, Kapolri, para Gubernur, Bupati dan Walikota untuk;a) meningkatkan kualitas pelayanan umum dalam bentuk pelayanan atau kemudahan-kemudahan yang diperlukan bagi wisatawan internasional yang hendak berkunjung ke Indonesia dan kemudahan bagi wisatawan local dalam melakukan perjalanan untuk mengenal dan mencintai alam dan ragam budaya Indonesia ;b) mengambil langkah- langkah nyata gunamengoptimalkan pelaksanaan pembangunan kebudayaan dan pariwisata nasional dalam upaya menyejahterakan masyarakat, membuka lapangan kerja, memberantas kemiskinan dan meratakan pembangunan; c)secara proaktif menjalankan upaya perlindungan, pengembangan peradaban dan pariwisata; d)menggunakan tema Indonesia Ultimate in Diversity (IUiD) dalam setiap kegiatan promosi yang dilakukan di luarnegeri dan tema-Kenali Negerimu Cinta Negerimu Ayo Tamasya Jelajahi Nusantaralldalam setiap kegiatan dalam negeri. Instruksi tersebut dilaksanakan sebaik-baiknya dengan setiap departemen terkait mendukung upaya peningkatan jumlah wisatawan dan pergerakan wisatawan domesticsehingga sumbangan sebesar-besarnya di sectorpariwisata terhadap perekonomian nasional, pembasmian kemiskinan penciptaan peluang kerja yang dapat dicapai.

10. Organisasi Pendukung dan Lingkungan Pemasaran

Agar pemasaran lebih efektif, manajemen pemasaran membentuk system perencanaan pemasaran, sistem organisasi pelaksanaan pemasaran, sistem pengendalianpemasaran dan sistem informasi pemasaran.

11. Pembentukan Kelompok Kerja

Kelompok kerja merancang program dan kegiatan agar wisatawan dapat tertarik oleh iklan dan didorong oleh industry untuk berkunjung ke Indonesia, sehingga wisatawan yang semula tidak ada niat berkunjung kemudian berubah menjadi berkunjung ke Indonesia. Tujuan kelompok kerja adalah untuk mendekati pengguna dengan cara tertentu agar wisatawan berpikir atau bertindak kemudian melakukan transaksi dan mengunjungi Indonesia.Salah 
satu tugas kelompok kerja adalah mengomunikasikan program, produk, insentif, nilai tambah wisatawan.

\section{Program Komunikasi Pemasaran Terpadu}

Proses komunikasi pemasaran terpadu menghadapi kesulitan karena masing-masing pengusaha pariwisata atau agen perjalanan Indonesia mempunyai pangsa pasar danstandar harga sendiri-sendiri. Dalam pemasaran yang sama, pengusaha pariwisata atau agen perjalanan mempunyai hubungan bisnis berbeda dengan mitra usahanya di luar negeri. Pemerintah dapat bertindak sebagai fasilitator agar para pelaku pariwisata dapat bersatu dalam menghadapi pemasaran global sesuai pengkhususan masing-masing. Pola kerja sama pemasaran antara bisnis (B2B) diharapkan dapat lebih berkembang dalam kelompok kerja.

\section{Media Baru (New Media)}

New Media merupakan media yang menggunakan internet, media online berbasis teknologi, berkarakter fleksibel, berpotensi interaktif dan dapat berfungsi secara privat maupun secara public (Mondry, 2008:13). Definisi lainmengemukakan media baru merupakan digitalisasi yang mana sebuah konsep pemahaman dari perkembangan zaman mengenai teknologi dan sains dari semua yang bersifat manual menjadi otomatis dan dari semua yang bersifat rumit menjadi ringkas.

Digital adalah sebuah metode yang kompleks dan fleksibel yang membuatnya menjadi sesuatu yang pokok dalam kehidupan manusia.Digital ini juga selalu berhubungan dengan media karena media ini adalah sesuatu yang terus berkembang dari media zaman dahulu (old media) sampai sekarang yang sudah menggunakan digital (modern media/new media).

Internet adalah salah satu bentuk dari media baru (newmedia). Internet dinilai sebagai alat informasi paling penting untuk dikembangkan kedepannya. Internet memiliki kemampuan untuk mengkode, menyimpan, memanipulasi dan menerima pesan (Ruben,1998:110). Internet merupakan sebuah media dengan segala karakteristiknya.Internet memilik teknologi, cara penggunaan, lingkup layanan, isi dan image sendiri. Internet tidak dimiliki, dikendalikan atau dikelola oleh sebuah badan tunggal tetapi merupakan sebuah jaringan computer yang terhubung secara intensional dan beroperasi berdasarkan protocol yang disepakati bersama. Teori media baru merupakan sebuah teori yang dikembangkan oleh PierreLevy, yang mengemukakan bahwa media baru merupakan teori yang membahas mengenai perkembangan media. Dalam teori media baru, terdapat dua pandangan, pertama yaitu pandangan interaksi sosial yang membedakan media menurut kedekatannya dengan interaksi tatap muka.

\section{METODOLOGI PENELITIAN}

Metode yang digunakan dalam penelitian ini adalah deskriptif kualitatif (Rakhmat, 2009: 25) menyatakan bahwa penelitian deskriptif ditujukan untuk: (1) mengumpulkan informasi aktual secara rinci yang melukiskan gejala yang ada, (2) mengidentifikasi masalah atau memeriksa kondisi damn praktek-praktek yang 
berlaku, (3) membuat perbandingan atau evaluasi, (4) menentukan apa yang dilakukan orang lain dalam menghadapi masalah yang sama dan belajar dari pengalaman mereka untuk menetapkan rencana dan keputusan pada waktu yang akan datang. Penelitian kualitatif adalah penelitian yang bermaksud untuk memahami fenomena tentang apa yang dialami oleh subjek penelitian. (Moleong, 2012: 6). Penelitian yang diangkat oleh penulis bersifat sosial sehingga penulis memilih metode deskriptif kualitatif dengan tujuan untuk meneliti objek secara mendalam dan untuk lebih dapat memahami tentang hal-hal yang berakitan dengan latar belakang subjek penelitian. Adapun pemodelan masalah adalah sebagai berikut:

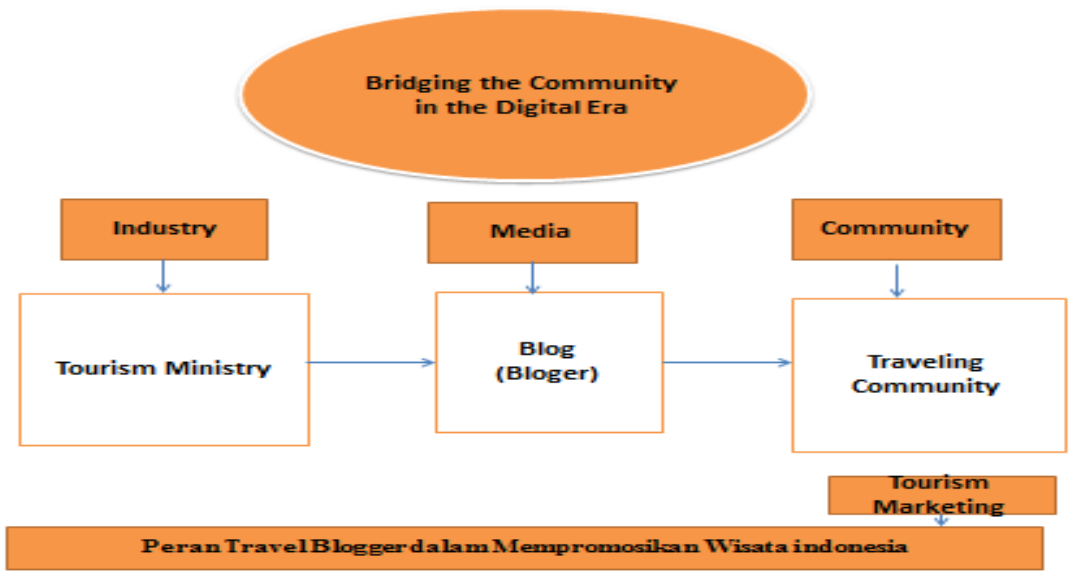

\section{HASIL DAN PEMBAHASAN}

Travel Blogger memiliki peran besar dalam mempromosikan pariwisata Indonesia melalui promosi di media online. Setiap blogger yang menuliskan pengalamannya di media blog dengan teknis menulisyang baik dilengkapi dokumentasi yang menarik akan mempengaruhi masyarakat luas untuk mengunjungi destinasi wisata yang dibahas dalam blog mereka. Hal ini diharapkan dapat membuka lapangan kerja dan memberikan nilai ekonomi bagi masyarakat daerah sasaran khususnya dan meningkatkan devisa negara Indonesia pada umumnya.

Peran travel Blogger ini diyakini oleh Kemenpar berperan dalam membantu menjalankan promosi yang dilakukan Kemenpar melalui Pesona Indonesia untuk wisata nusantara dan Wonderful Indonesia sebagai website resmi promosi pariwisata ke manca negara. Semua cerita yang disajikan dibalik pengalaman yang dirasakan langsung oleh para travel blogger dirasakan memberikan dampak positif bagi pencitraan Indonesia baik dimata masyarakat Indonesia sendiri maupun di mancanegara. berikut:

Tahapan yang dilakukan oleh travel blogger dapat diurutkan sebagai 


\section{Tahapan membangun awareness}

Selama proses penciptaan konten secara berkesinambungan dan konsisten, dikombinasikan antarteks, video dan foto dengan judul tulisan yang atraktif dan membangun keinginan orang untuk mau membaca dan memberikan response.

\section{Update Konten berkala}

Setiap hendak melakukan perjalanan, blogger telah membuat mapping point tentang tempat, budaya dan orang atau komunitas yangmenarik untuk didatangi berdasarkan prasurvey baik lewat pencarian di internet, pengalaman orang lain, rekomendasi teman yang bisa blogger hubungkan dengan pariwisata selama itu sesuai dengan passion and interestblogger itu sendiri.

\section{Strategi penulisan caption}

Blogger adalah penulis yang kekuatannya ada pada kata-kata. Gunakan bahasa yang mempromosikan menggunakan soft selling, yaitu kata-kata yang mampu menumbuhkan imajinasi positif di kalangan pembaca dan menggerakan pembaca untuk meresponse, pastikan pembaca mudah mendapatkan informasi lebih jauh dengan memberikan tautan hyperlink dengan benar, contact person dan contact number daerah tujuan dengan benar.

\section{Interaksi dengan follower}

Ciptakan engagement misalnya dengan memberikan apresiasi, temu blogger, interaksi yang memberikan perpanjangan lebih dari sekedar response tertulis, lebih bagus lagi bila blogger sudah memiliki pembaca setia yang selalu memfollow dan membantu shared tulisan yang dimuat oleh blogger

\section{Event dan Kerjasama}

Pesta Blogger yang sekarang telah rutin dilakukan, bukan hanya ajang pertemuan blogger namun juga ada pelatihan, diskusi dan sesi tukar pengalaman yang bertujuan menjadi bagian dari peningkatan skill dan memperluas network, selain komunitas para blogger yang banyak tersebar baik secara formal maupunnon formal seperti kaskus traveler, travel blogger Indonesia dan lain lain.

\section{Monitoring dan Evaluasi}

Evaluasiyang paling sering dilakukan adalah mengenai pengembangan konten, baik cara penulisan dan gaya menulis yang memiliki cara berbeda bagi setiap blogger namun hal ini dapat menjadi point kekuatan karena setiap gaya tulisan yang berbeda akan memberikan variasi dan alternatif bagi pembaca. Bentuk evaluasi lain adalah setting penempatan photo dan angle yang diambil agar bisa menjadi bagian dari kekuatan dari konten blog itu sendiri. Pembuatan video yang eksklusif dan dibuat secara professional akan melengkapi informasi tempat yang telah dibuat melalui tulisan dan photo. 


\section{SIMPULAN}

Dengan kelebihan yang dimiliki media blog bisa disinergikan dengan mediasosial menjadi alat yang sangat ampuh dalam mempromosikan pariwisata Indonesia, tulisan tentang keindahan alam Indonesia. Budaya setempat yang kaya dan interaksi spontan dengan penduduk asli Indonesia secara natural, berdasarkan pengalaman langsung dan antusias melalui passion akan lebih terasa gregetnya bagi pembaca karena menawarkan kejujuran dan orisinalitas yang pastinya bisa dirasakan langsung oleh pembaca. Blogger adalah actor utama yang berperan besar dalam mempromosikan pariwisata Indonesia selama memegang teguh kaidah jurnalisme dan tetap dapat independent dan menambah terus wawasan dan jam terbang perjalanan blogger.

Berdasarkan hasil penelitian dapat disimpulkan peran seorang travel blogger dalam mempromosikan Pariwisata Indonesia semakin strategis seiring dengan meningkatnya penggunaan media sosial sebagai bagian strategi Kementrian Pariwisata Republik Indonesia.

Adapun peran blogger yang terlihat menonjol dapat disimpulkan sebagai berikut:

1. Blogger sebagai kontributor

Blogger adalah kontributor independent yang memiliki peran strategis untuk memberikan konten yang variatif dan informatif melalui blog mereka yang dapat dihubungkan langsung ke blog resmi Kementerian dan Pariwisata Republik Indonesia dengan kemampuan menghibur melalui tulisan dan pengalaman langsung mereka di lokasi pariwisata yang dikunjunngi.

2. Blogger sebagai pengamat.

Kelebihan yang dimiliki seorang blogger salah satunya adalah pengalamannya mengunjungi berbagai tempat pariwisata di Indonesia. Pengalaman ini memberi kontribusi dalam menghasilkan pengamatan tajam mengenai kondisi nyata lokasi yang didatangi sehingga menyampaikan opini secara kaya dan objektif sekaligus kritis juga inovatif sehingga pembaca mendapatkan gambaran utuh mengenai lokasi pariwisata yang dijadikan objek tulisan.

3. Blogger sebagai promotor.

Kepekaan seorang blogger yang terlatih menggunakan panca inderanya secara lebih dalam membuatnya mampu menuangkan perasaan dan pengamatannya melalui tulisan yang bernas, menarik dan menumbuhkan imajinasi bagi para pembacanya. Tulisan yang menarik dapat membangun kesan mendalam bagi para pembacanya, memainkan emosi dan menumbuhkan rasa keingintahuan para pembacanya dalam upaya menyampaikan pesan sekaligus memberikan nilai tambah.

4. Blogger sebagai evaluator.

Blogger independen dalam memberikan opininya dan menuangkan dalam bentuk tulisan selayaknya memastikan diri mereka tetap kritis dan bersedia menyampaian pendapat mereka secara terbuka, jujur dan santun. Kredibilitas yang dimiliki seorang blogger akan memberikan nilai lebih bukan hanya pada penulisnya namun pada media yang terhubung padanya. 
Kepercayaan yang didapat dari pembaca berasal dari kejujuran seorang blogger dalam menyampaian evaluasi dari apa yang mereka alami secara langsung di lokasi pariwisata yang mereka kunjungi.

\section{DAFTAR PUSTAKA}

Alma, Buchari. (2014). Manajemen Pemasaran dan Pemasaran Jasa. Bandung: Alfabet.

Bungin, Burhan. (2007). Penelitian Kualitatif: Komunikasi Ekonomi Kebijakan Publik dan Ilmu Sosial Lainnya. Jakarta: Kencana.

Bungin, (2015). Komunikasi Pariwisata: Pemasaran dan Brand Destinasi. Bandung: Prenada Group.

Basu, Swastha \&Irawan. (2001). Manajemen Pemasaran Modern, Yogyakarta: Liberty.

C. Ruben Bentand Lea, P.Stewart (1998). Communications and Human Behavior. USA: Allyn \& Bacon

Djadjasudarma, T.Fatimah. (2006). Metode Linguistik: Ancangan Metode Penelitian dan Kajian. Bandung: PT Refika Aditama.

Effendy, Onong Uchana. (1993). Ilmu Teori \&FilsafatKomunikasi. Bandung: PT. Citra Aditya Bakti.

Hafsah, Muhammad Jafar. (1999). Kemitraan Usaha. Jakarta: Pustaka Sinar Harapan.

Ismayanti. (2010). Pengantar Pariwisata. Jakarta: PT. Gramedia Widisarana Indonesia

Juju, Sulianta. (2009). Branding Promotion with Social Networks. Jakarta: PT. Elex Media Komputindo.

Moleong, LexyJ. (2002). Metode Penelitian Kualitatif. Jakarta:PT. Elex Media Komputindo

Mondry.(2008). Pemahaman Teori dan Praktik Jurnalistik. Bogor: Ghalia Indonesia.

Morrisan.(2010). Periklanan: Komunikasi Pemasaran Terpadu.Jakarta: Kharisma Putra Utama.

Rangkuti, Freddy. (2009). Strategi Promosi yang Kreatif dan Analisis Kasus Integrated Marketing Communication. Jakarta: Gramedia

VanDijk, J.A.G.M.(2006).The Network Society. London: SAGE Publications,

Zarella, Dan. (2010). The Social Media Marketing Books. Sebastopol: O'ReillyMedia,

Severin, Tankard (2011). Teori Komunikasi: Sejarah, Metode, danTerapan di Dalam Media Massa. Bandung: Prenada Group

Suryadana, Ligadan Vanny Octavia (2015). Pengantar Pemasaran Pariwisata.Bandung: Alfabeta

Tjiptono, F. (2000). Perspektif Manajemen dan Pemasaran Kontemporer. Yogyakarta: ANDI. 
Tim Pusat Humas Kementrian Perdagangan RI. (2014). Panduan Optimalisasi Media Sosial untuk Kementrian Perdagangan RI. Jakarta Pusat. Pusat Hubungan Masyarakat Republik Indonesia.

Yoeti, Oka. (1983) Pengantar Ilmu Pariwisata. Bandung: Angkasa.

LiteraturArtikel

www.wearesocial.sg. www.tekno.tempo.com 